\title{
Understanding Insurance Knowledge: A Brief 7-Item Measure
}

\author{
Evita Allodi ${ }^{1}$, Enrico M. Bocchino ${ }^{2} \&$ Gian P. Stella ${ }^{3}$ \\ ${ }^{1}$ Department of Economic and Management, University of Parma, Italy \\ ${ }^{2}$ Department of Law, University of Turin, Italy \\ ${ }^{3}$ Department of Management and Law, University of Rome "Tor Vergata", Italy \\ Correspondence: Evita Allodi, Department of Economic and Management, University of Parma, Parma, 43125, \\ Italy. E-mail: evita.allodi@unipr.it
}

Received: December 3, 2020

Accepted: January 10, 2021

Online Published: January 20, 2021

doi:10.5539/ijbm.v16n2p65

URL: https://doi.org/10.5539/ijbm.v16n2p65

\begin{abstract}
The conceptualisation of the insurance culture and the identification of a standard measuring instrument are the first steps towards defining a literate consumer. Obviously knowledge, understood as the ability to understand and use concepts in a conscious way, is considered to be a key variable for measuring the levels of many conceptual definitions of literacy, so also for insurance literacy.

The aim of our research is precisely to verify the validity and reliability of a questionnaire that is composed of 7 questions that can represent a tool for measuring the level of insurance knowledge of consumers. The questions investigate the mere knowledge of insurance definitions and concepts, without going into too much detail about specific types of policies. To pursue this goal, a factor analysis has been conducted through a sample that is composed of 274 Italian respondents. The results show that those items are able to measure the basic insurance knowledge of a consumer.
\end{abstract}

Keywords: Explanatory Factor Analysis, Insurance Knowledge, Insurance Literacy, Item Validation, Reliability JEL Codes: G20, G22, D80, D83.

\section{Introduction}

Financial literacy, defined as "knowledge and understanding of financial concepts and risks, and the skills, motivation and confidence to apply such knowledge and understanding in order to make effective decisions across a range of financial contexts, to improve the financial well-being of individuals and society, and to enable participation in economic life" (OECD 2014), is the key to making informed financial decisions. Similarly, insurance literacy enables consumers to make insurance decisions.

While financial literacy has been studied and deepened from many points of view, studies on insurance literacy are still limited. One possible justification for not developing this line of research is the lack of official criteria to classify a "literate" consumer (Tennyson, 2011).

The few resources available show that the level of insurance literacy of the "average" consumer is low (Cummins, McGill, Winklevoss \& Zelten, 1974; Joiner, Leveson \& Langfield-Smith, 2002; Cude, 2005; Tennyson, 2010).

To measure a consumer's level of insurance literacy, as well as financial literacy, multiple variables can play a key role. Among these, insurance knowledge, understood as the ability to understand and use insurance concepts in a conscious way, is the discriminating factor that helps the consumer to make conscious and specific choices for his or her needs. According to some researchers (Gine, Townsend \& Vickery, 2008; Tennyson, 2011; Cole, Gine, Tobacman, Topalova, Townsend \& Vickery, 2013; Driver, Brimble, Freudenberg \& Hunt, 2018; Lin, Bruhn \& William, 2019), consumers without insurance knowledge and the important role it plays do not consider the insurance policy a risk management tool. For this reason, consumers often tend not to insure themselves, or to insure themselves inadequately, and are thus under-insured when an adverse event occurs (Rice, 2016; Lin et al., 2019).

As insurance products and services form a significant part of the national economy of major industrialised countries and play an essential role in family budget financial planning (OECD, 2008; Tennyson, 2011; ASIC, 
2014; ANZ, 2015), institutions around the world have attempted to remedy the problem by imposing rules and regulations for intermediaries to follow. For example, the Insurance Distribution Directive, the new European Directive on the distribution of life and non-life insurance products, has recently been introduced in Europe. This is a new set of rules aimed at placing the actual needs of the client at the centre of the logic of product construction and distribution. This operating mode is possible thanks to the revision of pre-contractual and contractual documentation in order to allow the consumer comparability between products, profiling of actual needs, and greater transparency.

Some research has shown that insurance policy information materials are written in a complex and difficult to understand way (Pati et al., 2012; Vardell, 2013). In addition to guaranteeing transparency, some American states have imposed "simple language" requirements aimed at reducing the use of courtly and complex language in favour of commonly used terms (Stempel, 2006). In addition to this, some states have imposed a minimum requirement for the readability of insurance contracts. (NAIC, 2010). The readability of a contract is measured by an index called the Flesch Reading Ease Score, which is determined by applying an algebraic formula using syllable count and sentence length in the contract. Despite the efforts made by the scientific community and institutions to address this problem to date, not only does the problem persist, but it has not yet been analysed and resolved at the source; i.e., it is still unclear what discriminators determine a consumer who is not literate in the insurance field and consequently what impact this has on his or her decision whether or not to take out insurance against certain unfavourable events. It is necessary to create a tool for measuring insurance literacy.

Our contribution to scientific research consists in the creation of a tool for measuring insurance knowledge. This instrument actually consists of a questionnaire of 7 multiple-choice questions, that is useful for determining the level of insurance knowledge of an individual and also able to highlight what are the conceptual gaps of respondents. The questions investigate the mere knowledge of insurance definitions and concepts, without going into too much detail about specific types of policies; for each question there is only one correct answer. To test the usability and thus the replicability of the tool, we conducted an exploratory factorial analysis of 274 observations. The work is organised as follows. In section 2, we present the literature review, in section 3 , we present the methodology, in section 4 , we present the results, and in section 5, we outline our conclusions.

\section{Literature Review}

Despite its importance, the scientific community recognises that there is little research activity on insurance literacy and measurement (Huston 2010; Tennyson 2011, Sanjeewa \& Hongbing 2019). This is why there is currently no recognised definition of insurance literacy, and the concepts of insurance knowledge, literacy, and education are used interchangeably (ANZ, 2008; McCormack, Uhrig, Berkman \& Rudd, 2009; Beal \& Delpachitra, 2010; NAIC, 2010; ANZ, 2011; Bonan, Dagnelie, Lemay-Boucher \& Tenikue, 2011; NCAER, 2011; Tennyson, 2011; Olapade \& Frolich, 2012; Cude, Kunovskaya, Kabaci \& Henry, 2013; Core Data, 2014; Ramteke, 2014; ANZ, 2015; Dalkilic \& KirkBesoglu, 2015; Wells, Epermanis \& Gibson, 2015; Dillingh, Kooreman \& Potters, 2016; Kawinski \& Majewski, 2016; Bonan, Dagnelie, Lemay-Boucher \& Tenikue, 2017; GIZ, 2017; Uddin, 2017; Urbanovsky \& Nesleha, 2017; Driver et al., 2018; Tilley, Yarger \& Brindis, 2018).

The conceptualisation of the insurance culture and the identification of a standard measuring instrument are the first step towards defining a literate consumer.

The aim of our research is precisely to create, through the use of a questionnaire, a tool for measuring insurance basic knowledge of consumers without going into too much detail about specific types of policies. To do this, first of all, it was decided to use the methodology of the literature review as it can highlight any gaps in the literature (Baggio \& Valeri, 2020). For this reason, the work previously carried out by other researchers has been analysed.

Through the main electronic databases, the most relevant studies have been selected through questionnaires bearing the following keywords: "Insurance Literacy", "Financial and Insurance Literacy", "Financial and Insurance Education", "Insurance Knowledge".

As shown in Table 1, the studies that dealt with the issue of insurance literacy through a questionnaire amounted to 21 . 
Table 1. List of studies conducted by questionnaire to study insurance literacy

\begin{tabular}{|c|c|c|c|c|c|c|}
\hline$\#$ & Year & Authors & $\begin{array}{c}\text { Basic Financial } \\
\text { Knowledge }\end{array}$ & $\begin{array}{c}\text { *Basic Insurance } \\
\text { Knowledge }\end{array}$ & $\begin{array}{c}\text { Specific Insurance } \\
\text { Knowledge }\end{array}$ & $\begin{array}{c}\text { Rating } \\
* *\end{array}$ \\
\hline 1 & 1983 & Marquis & & & $\mathrm{X}$ & \\
\hline 2 & 1998 & Chen and Volpe & $\mathrm{X}$ & $\mathrm{X}$ & $\mathrm{X}$ & \\
\hline 3 & 2003 & Beal and Delpachitra & $\mathrm{X}$ & & $\mathrm{X}$ & $\mathrm{x}$ \\
\hline 4 & 2008 & Mandell & $\mathrm{X}$ & & $\mathrm{X}$ & \\
\hline 5 & 2011 & Tennyson & & $\mathrm{X}$ & $\mathrm{X}$ & $\mathrm{X}$ \\
\hline 6 & 2011 & NCAER & $\mathrm{X}$ & & $\mathrm{X}$ & \\
\hline 7 & 2012 & Olapade and Frolich & $\mathrm{X}$ & & $\mathrm{X}$ & $\mathrm{X}$ \\
\hline 8 & 2013 & Mahdzan and Victorian & & & $\mathrm{X}$ & \\
\hline 9 & 2013 & Cude et al & $\mathrm{X}$ & & $\mathrm{X}$ & \\
\hline 10 & 2014 & CoreData & & & $\mathrm{X}$ & $\mathrm{X}$ \\
\hline 11 & 2014 & Paez et al & & & $\mathrm{X}$ & \\
\hline 12 & 2014 & Ramteke & & & $\mathrm{X}$ & \\
\hline 13 & 2015 & $\begin{array}{l}\text { Dalkilic and } \\
\text { Kirkbesoglu }\end{array}$ & $\mathrm{X}$ & & & \\
\hline 14 & 2015 & Wells et al & & & $\mathrm{X}$ & \\
\hline 15 & 2016 & Politi et al & & & $\mathrm{X}$ & \\
\hline 16 & 2016 & $\begin{array}{l}\text { Kawinski } \\
\text { Majewski }\end{array}$ & $\mathrm{X}$ & $\mathrm{X}$ & & \\
\hline 17 & 2017 & Uddin & & & $\mathrm{X}$ & $\mathrm{X}$ \\
\hline 18 & 2017 & Bonan et al & & & $\mathrm{X}$ & \\
\hline 19 & 2018 & McLeod and Adepoju & & & $\mathrm{X}$ & \\
\hline 20 & 2019 & Lin et al & $\mathrm{X}$ & & & $\mathrm{X}$ \\
\hline 21 & 2019 & Sanjeewa et al & & $\mathrm{X}$ & $\mathrm{X}$ & \\
\hline
\end{tabular}

The table shows that most of the previous studies $(85.7 \%)$ focused on insurance questions specific to a particular non-life or life-line of business, while only 4 out of 21 studies asked questions about general insurance concepts that could not be subject to a specific instrument.

A number of studies have asked questions about finance, as previous studies on financial literacy have identified insurance as a particular category of finance itself (Huston, 2010; Remund, 2010; Zait \& Bertea, 2014; Lin et al., 2019), although Lin et al. (2019) show that financial literacy does not necessarily translate into insurance literacy. Overall, there are two shortcomings which, in our view, have affected the results of previous research. The first, which brings all studies together and at the same time differentiates them in the research objective, is the lack of a definition of insurance literacy to refer to.

In general, the concept of literacy refers to the notions, knowledge and skills needed to understand and use information related to a specific topic.

According to Sampath Sanjeewa and Hongbing (2019), insurance literacy can be defined as a combination of knowledge, skills, attitudes, and behaviour necessary to make an informed insurance decision based on potential risk exposure and individual circumstances.

Obviously, knowledge is the most common component of many conceptual definitions of literacy.

Again, Sampath Sanjeewa and Hongbing (2019) state that "insurance knowledge is divided into six sub-areas: 1). Understanding potential risk exposure, 2). Risk mitigation strategies, 3). Insurance concept, principles and benefit, 4). Insurance products and covers 5). Rights and duties of insured, and 6). Information sources".

We believe that insurance literacy is a construct composed of 3 components: insurance knowledge, insurance understanding and insurance skills and attitudes (Allodi, Cervellati \& Stella, 2020).

These three components determine a consumer's degree of literacy and help him or her to make part of his or her decision about whether or not to buy an insurance product or service. However, this is not sufficient because the consumer's final decision depends on an intrinsic behavioural component of each individual that cannot be included in the concept of insurance literacy. We believe that knowledge is the component that plays a 
predominant role in determining the level of insurance literacy of a consumer, so we think that knowledge should be measured by distinguishing between the simplest knowledge, regarding insurance concepts and principles in general, and advanced knowledge, regarding the characteristics of the various products and lines of business.

This differentiation of knowledge is the second shortcoming of the studies carried out so far, i.e., the lack of a measurement indicator that considers an assessment of the level of insurance knowledge by distinguishing between basic and advanced level questions. Only Tennyson (2011) proposes a questionnaire with questions referring both to specific products and to general concepts of the insurance world, but he measures insurance literacy through the percentage analysis of the answers to the questions, referring indiscriminately to the concept of insurance literacy and insurance knowledge.

In order to solve this problem, we propose a new questionnaire that takes into account the shortcomings exposed and focuses its questions on basic insurance knowledge.

\section{Method}

\subsection{Description of the Survey}

The focus of our research refers to the relation between knowledge and insurance among Italian citizens. To do so, we designed a questionnaire. The assessment was used to measure the levels of Insurance knowledge. The survey was fielded in November 2019. The data were collected during the period January-February 2020 through an online survey. The sample is composed of 274 Italian respondents. We can define our sample as a convenience sample, as several university students and former students, relatives and friends were involved, and a voluntary response sample cause the link to access to the questionnaire was posted online through the groups of the main social network.

The survey reports information on several demographic characteristics such as age, gender, and education. In Table 2, we describe the variables that we use and how we codified them for the analyses that follow.

Table 2. Variables description

\begin{tabular}{ll}
\hline Variable & Description \\
\hline Age & Age (Period from 13 January 2020 until 28 February 2020) \\
Gender & Female $=2 ;$ Male $=1$ \\
Civil Status & Unmarried $=1 ;$ Married $=2$; Divorced $=3$; Widowed $=4$ \\
Education & $0-9$ Years $=1 ; 9-12$ Years $=2 ;$ More than 12 Years $=3$ \\
Work status & Unemployed $=0 ;$ Student $=1 ;$ Retired $=2 ;$ Part-time work $(<35$ hours $/$ week $)=3 ;$ Full-time work $(>35$ hours $/$ week $)=4$ \\
Income & Less than $€ 10000=1 ;$ Between $€ 10000$ and $€ 20000=2 ;$ Between $€ 20000$ and $€ 40000=3$ Between $€ 40000$ and $€ 80$ \\
& $000=4 ;$ More than $€ 80000=5 ;$ Refuse to answer $=99$ \\
\hline
\end{tabular}

\subsection{Measures}

In this work, seven questions have been tested to measure insurance knowledge. In particular, these questions were developed to assess financial insurance concepts. The correct option is scored as 1 and the wrong option as zero. Finally, following the methodology in this research, the response "I do not know" and "Prefer not to say" are considered wrong. (Table 3). 
Table 3. Insurance knowledge questions

\begin{tabular}{|c|c|c|c|c|c|c|}
\hline Item & $\begin{array}{l}\text { Insurance } \\
\text { Knowledge }\end{array}$ & Option 1 & Option 2 & Option 3 & Option 4 & Option 5 \\
\hline 1 & $\begin{array}{l}\text { How do you } \\
\text { define the part } \\
\text { of the loss, } \\
\text { expressed as a } \\
\text { percentage, } \\
\text { which remains } \\
\text { the } \\
\text { responsibility of } \\
\text { the insured } \\
\text { party? }\end{array}$ & Ceiling & Deductible & Discovered & $\begin{array}{l}\text { I don't } \\
\text { know }\end{array}$ & $\begin{array}{l}\text { Prefer not } \\
\text { to say }\end{array}$ \\
\hline 2 & $\begin{array}{l}\text { What is an } \\
\text { index-linked } \\
\text { policy? }\end{array}$ & $\begin{array}{l}\text { The insurance contract } \\
\text { in which benefits are } \\
\text { exclusively linked to } \\
\text { the occurrence of events } \\
\text { such as death, } \\
\text { disability, or incapacity } \\
\text { of the insured person }\end{array}$ & $\begin{array}{l}\text { A life insurance } \\
\text { contract in which the } \\
\text { benefits are directly } \\
\text { linked to the value of } \\
\text { the assets contained in } \\
\text { an internal fund held by } \\
\text { the insurance company, } \\
\text { or to the value of the } \\
\text { units of the Organismo } \\
\text { Investimento Collettivo } \\
\text { Risparmio (collective } \\
\text { investment body } \\
\text { undertaking). }\end{array}$ & $\begin{array}{l}\text { A life insurance contract } \\
\text { where the benefits are } \\
\text { directly linked to a stock } \\
\text { index or other reference } \\
\text { value }\end{array}$ & $\begin{array}{l}\text { I don't } \\
\text { know }\end{array}$ & $\begin{array}{l}\text { Prefer not } \\
\text { to say }\end{array}$ \\
\hline 3 & $\begin{array}{l}\text { Is it possible to } \\
\text { take out a motor } \\
\text { liability policy } \\
\text { with retroactive } \\
\text { effect? }\end{array}$ & Yes & No & $\begin{array}{l}\text { Yes, only if no claim has } \\
\text { occurred between the } \\
\text { effective date and the date } \\
\text { of conclusion of the } \\
\text { contract }\end{array}$ & $\begin{array}{l}\text { I don't } \\
\text { know }\end{array}$ & $\begin{array}{l}\text { Prefer not } \\
\text { to say }\end{array}$ \\
\hline 4 & $\begin{array}{l}\text { In insurance } \\
\text { contracts, the } \\
\text { risk is: }\end{array}$ & The Cause & An essential element & An accidental element & $\begin{array}{l}\text { I don't } \\
\text { know }\end{array}$ & $\begin{array}{l}\text { Prefer not } \\
\text { to say }\end{array}$ \\
\hline 5 & $\begin{array}{l}\text { In life } \\
\text { insurance, the } \\
\text { "full life" form } \\
\text { provides: }\end{array}$ & $\begin{array}{l}\text { Payment to the } \\
\text { beneficiaries of a sum in } \\
\text { the event of the death of } \\
\text { the insured }\end{array}$ & $\begin{array}{l}\text { The payment of an } \\
\text { annuity from the date of } \\
\text { expiry of the contract. }\end{array}$ & $\begin{array}{l}\text { Payment of a lump sum on } \\
\text { expiry of the contract if the } \\
\text { insured member is still } \\
\text { alive }\end{array}$ & $\begin{array}{l}\text { I don't } \\
\text { know }\end{array}$ & $\begin{array}{l}\text { Prefer not } \\
\text { to say }\end{array}$ \\
\hline 6 & $\begin{array}{l}\text { What is an } \\
\text { individual } \\
\text { pension plan? }\end{array}$ & $\begin{array}{l}\text { It is a form of retirement } \\
\text { pension realised } \\
\text { through the } \\
\text { underwriting of a life } \\
\text { insurance contract with } \\
\text { a pension purpose }\end{array}$ & $\begin{array}{l}\text { It is an individual } \\
\text { sepplementary pension } \\
\text { form }\end{array}$ & $\begin{array}{l}\text { It is a complementary form } \\
\text { of pension to which only a } \\
\text { person who is employed } \\
\text { can join individually. }\end{array}$ & $\begin{array}{l}\text { I don't } \\
\text { know }\end{array}$ & $\begin{array}{l}\text { Prefer not } \\
\text { to say }\end{array}$ \\
\hline 7 & $\begin{array}{l}\text { Participation in } \\
\text { a form of } \\
\text { supplementary } \\
\text { pension } \\
\text { provision: }\end{array}$ & It is never mandatory & $\begin{array}{l}\text { It can happen only if } \\
\text { provided for by the } \\
\text { National Collective } \\
\text { Labour Contract }\end{array}$ & Can only be made to a fund & $\begin{array}{l}\text { I don't } \\
\text { know }\end{array}$ & $\begin{array}{l}\text { Prefer not } \\
\text { to say }\end{array}$ \\
\hline
\end{tabular}

\section{Results}

\subsection{Descriptive Analysis}

Table 4 illustrates the descriptive statistics for the sample of respondents to the questionnaire. The age of the respondents ranges from 20 to 90 years. The average age of the respondents is 34.91 years, and the standard deviation (SD) is 11.20 . 
Table 4. Sample descriptive statistics

\begin{tabular}{lccccc}
\hline Variables & No. of observations & Mean & Standard Deviations & Max & Min \\
\hline Age & 274 & 20 & 90 & 34.91 & 15.965 \\
Gender & 274 & 1 & 2 & 1.427 & 0.49555 \\
Civil Status & 274 & 1 & 4 & 1.6423 & 0.72866 \\
Education & 274 & 0 & 2 & 1.427 & 0.53807 \\
Work Status & 274 & 0 & 4 & 2.4854 & 1.4251 \\
Income & 194 & 1 & 5 & 2.5722 & 1.11859 \\
\hline
\end{tabular}

In Table 5, we present the frequency tables related to the variables available in our dataset. Among socioeconomic characteristics, we considered age, gender, civil status, education levels, work status, and income.

Table 5. Frequency table

\begin{tabular}{|c|c|c|c|c|c|}
\hline & & No & Percentage $\%$ & Cumulative \% & $p$ \\
\hline \multirow[t]{8}{*}{ Age } & & & & & $* * *$ \\
\hline & $18-25$ years old & 122 & 44.5 & 44.5 & \\
\hline & 26 - 35 years old & 48 & 17.5 & 62 & \\
\hline & 36 - 45 years old & 46 & 16.8 & 78.8 & \\
\hline & 46 - 55 years old & 23 & 8.4 & 87.2 & \\
\hline & 56 - 65 years old & 18 & 6.6 & 93.8 & \\
\hline & $65-75$ years old & 10 & 3.6 & 97.4 & \\
\hline & $>75$ years old & 7 & 2.6 & 100 & \\
\hline \multirow[t]{3}{*}{ Gender } & & & & & $* * *$ \\
\hline & Female & 134 & 47.9 & 47.9 & \\
\hline & Male & 140 & 52.1 & 100 & \\
\hline \multirow[t]{5}{*}{ Civil Status } & & & & & $* * *$ \\
\hline & Married & 109 & 39.8 & 39.8 & \\
\hline & Single/Unmarried & 134 & 48.9 & 88.7 & \\
\hline & Divorced & 26 & 1.8 & 98.2 & \\
\hline & Widowed & 5 & 1.8 & 100 & \\
\hline \multirow[t]{4}{*}{ Education } & & & & & $* * *$ \\
\hline & $<0-9$ Years & 6 & 2.2 & 2.2 & \\
\hline & $9-12$ Years & 145 & 52.9 & 55.1 & \\
\hline & $>12$ Years & 123 & 44.9 & 100 & \\
\hline \multirow[t]{6}{*}{ Work Status } & & & & & $* * *$ \\
\hline & Full-Time Work & 119 & 43.4 & 43.4 & \\
\hline & Part- Time Work & 17 & 6.2 & 49.6 & \\
\hline & Retired & 18 & 6.6 & 56.2 & \\
\hline & Student & 118 & 43.1 & 99.3 & \\
\hline & Unemployed & 2 & 0.7 & 100 & \\
\hline \multirow[t]{7}{*}{ Income } & & & & & $* * *$ \\
\hline & Less than $€ 10000$ & 38 & 13.9 & 13.9 & \\
\hline & $€ 10000-€ 20000$ & 55 & 20.1 & 33.9 & \\
\hline & $€ 20000-€ 40000$ & 64 & 23.4 & 57.3 & \\
\hline & $€ 40000-€ 80000$ & 26 & 9.5 & 66.8 & \\
\hline & $€ 80000$ or more & 11 & 4 & 70.8 & \\
\hline & Prefer not to say & 80 & 29.2 & 100 & \\
\hline
\end{tabular}

\subsection{Factor Analysis}

We conducted a factor analysis (using SPSS 26 software). As reported in Table 6, the Kaiser-Meyer-Olkin (KMO) index is equal to .789 , whereas the Bartlett test is significant $(\mathrm{p}=.000)$. These results reject the null hypothesis that the matrix of correlations between variables is an identity matrix (Hair, Anderson, Tatham \& Black, 1995). 
Table 6. KMO and Bartlett's test

\begin{tabular}{ll}
\hline Kaiser-Meyer-Olkin Measure of Sampling Adequacy. & .789 \\
\hline Bartlett's Test of Sphericity (Approx. Chi-Square) & 246.403 \\
df & 28 \\
Sig. & .000 \\
\hline
\end{tabular}

According to the K1 criterion (Kaiser, 1960), factor analysis proposes the extraction of one factor, which explains in cumulative terms $31.19 \%$ of the variance. The number of factors to be extracted for this analysis, equal to one, is confirmed by the scree plot. (Figure 1).

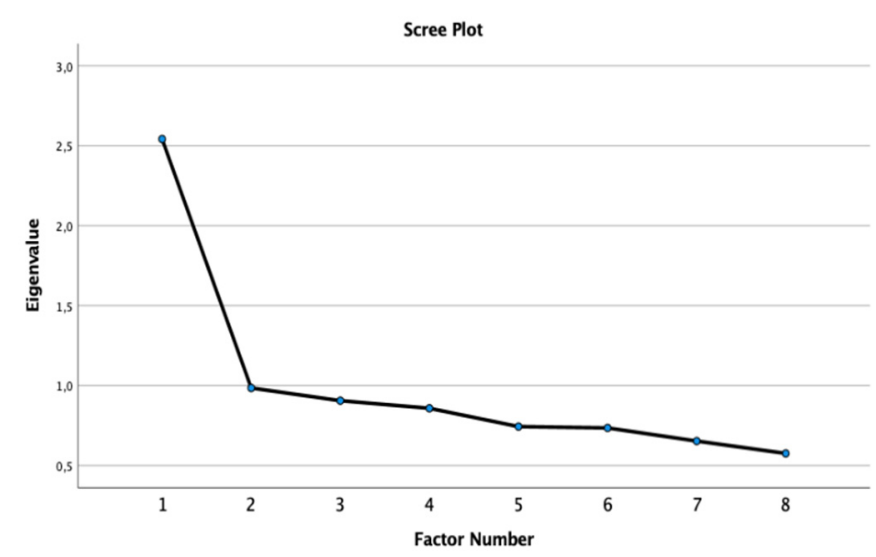

Figure 1. Scree plot

Table 7 presents the results from the factor analysis. We considered one factor related to respondents' insurance knowledge. The factor decomposition is implemented via maximum likelihood (ML) factor analysis with the Promax method (Costello \& Osborne, 2005). The Pattern matrix shows that there is only one factor that represents the insurance knowledge. Furthermore, Cronbach's alpha for all questions is higher than 0.65. In particular, this result demonstrates that these questions can be used to analyse insurance knowledge.

Table 7. Factor analysis

\begin{tabular}{lcc}
\hline Components & Item & $\begin{array}{c}\text { Insurance } \\
\text { Knowledge }\end{array}$ \\
\hline What is an index-linked policy? & 2 & .53 \\
Participation in a form of supplementary pension provision: & .51 \\
What is an individual pension plan? & 7 & .469 \\
In life insurance, the "full life" form provides: & 5 & .453 \\
Is it possible to take out a motor liability policy with retroactive effect? & 3 & .441 \\
How do you define the part of the loss, expressed as a percentage, which remains the responsibility of the & 1 & .436 \\
insured party? & 4 & .41 \\
In insurance contracts the risk is: & .654 \\
$\alpha$ & 288.36 \\
M & 197.89 \\
SD & & 2 \\
Methods: Maximum likelihood (ML), Promax with Kaiser Normalization & & \\
\hline
\end{tabular}

\section{Conclusions}

We propose and validate a new insurance knowledge questionnaire to test one of the three dimensions identified to define the concept of consumer insurance literacy. The econometric analyses conducted on the questionnaire have established how the questions developed on insurance knowledge are able to measure basic insurance knowledge without going into the details of particular types of policies. The reliability analyses carried out on 
the questions in the questionnaire that we developed showed that they are reliable and replicable, thanks to the calculation of Cronbach's alpha which is greater than 0.6. The factor analysis demonstrated the robustness of the questionnaire. From the research point of view, this study has some advantages.

First of all, it is a small step forward compared to previous studies. Having a validated questionnaire that allows one to investigate the phenomenon of insurance literacy through the basic knowledge of insurance issues on the part of individuals is an incentive to face more in-depth analysis and to investigate if and how the variables identified as significant for financial literacy also play a fundamental role in the insurance sphere. The replicability of the questionnaire will allow it to be tested on individuals of different generations and ages and above all from culturally different backgrounds; diversity will be a crucial aspect in the evolution of the surveys.

Secondly, one aspect that should not be underestimated is the length of the questionnaire. Since there are only seven insurance knowledge questions, the questionnaire does not take long to complete, and it can be completed and replicated in just five minutes.

However, the research has one limitation - it does not provide a scale for measuring insurance literacy, but only insurance basic knowledge.

Our goal for the future is to expand the questionnaire by including three more sections, i.e. questions on advanced knowledge, understanding, skills and attitude, in order to provide a comprehensive scale for measuring insurance literacy.

\section{References}

Allodi, E., Cervellati, E. M., \& Stella, G. P. (2020). A new proposal to define Insurance Literacy: paving the path ahead. Risk Governance \& Control: Financial Markets \& Institutions, 10(4), 22-32. http://doi.org/10.22495/rgcv10i4p2

ANZ. (2008). ANZ Survey of Adult Financial Literacy in Australia. Australia.

ANZ. (2011). Adult Financial Literacy in Australia. Full Report of the results from the 2011 ANZ Survey. Australia.

ANZ. (2015). ANZ Survey of Adult Financial Literacy in Australia Full Report of the Results from the 2014 ANZ survey. Melbourne: The Social Research Centre.

ASIC. (2014). National Financial Literacy Strategy 2014-17. Australian Securities and Investments Commission.

Baggio, R., \& Valeri, M. (2020). Network science and sustainable performance of family businesses in tourism. Journal of Family Business Management, https://doi.org/10.1108/JFBM-06-2020-0048

Beal, D. J., \& Delpachitra, S. B. (2003). Financial Literacy Among Australian University Students. Economic Papers, 22 (1), 65-78.

Bonan, J., Dagnelie, O., Lemay-Boucher, P., \& Tenikue, M. (2017). The Impact of Insurance Literacy and Marketing Treatments on the Demand for Health Micro-insurance in Senegal: A Randomised Evaluation. Journal of African Economies, 26(2), 169-191. https://doi.org/10.1093/jae/ejw023

Bonan, J., Dagnelie O., Lemay-Boucher P., \& Tenikue, M. (2011). Is it all about Money? A Randomized Evaluation of the Impact of Insurance Literacy and Marketing Treatments on the Demand for Health Micro-insurance in Senegal. Research Paper No. 14. Micro-insurance Innovation Facility. Geneva: ILO). http://repec.dems.unimib.it/repec/pdf/mibwpaper216.pdf

Chen, H., \& Volpe, R. P. (1998). An Analysis of Personal Financial Literacy Among College Students. Financial Services Review, 7(2), 107-128. https://doi.org/10.1016/s1057-0810(99)80006-7

Cole, S., Gine, X., Tobacman, J., Topalova, P., Townsend, R., \& Vickery, J. (2013). Barriers to household risk management: Evidence from India. American Economic Journal: Applied Economics, 5(1), 104-135. https://doi.org/10.1257/app.5.1.104

COREDATA. (2014). The Life Insurance Literacy Gap (Zurich Financial Services Australia and Financial Planning Association of Australia. Sydney.

Costello, A. B., \& Osborne, J. (2005). Best practices in exploratory factor analysis: Four recommendations for getting the most from your analysis. Practical Assessment, Research, And Evaluation, 10(1), 7.

Cude, B. (2005). Insurance disclosures: An effective mechanism to increase consumers' market power? Journal of Insurance Regulation, 24(2), 57-80. 
Cude, B. J., Kunovskaya, I., Kabaci, M. J., \& Henry, T. (2013). Assessing Changes in the Financial Knowledge of College Seniors. American Council on Consumer Interests, 59.

Cummins, J. D., McGill, D. M., Winklevoss H. E., \& Zelten, H. A. (1974). Consumer Attitudes Toward Auto and Homeowners Insurance, Department of Insurance. Wharton School, University of Pennsylvania, Philadelphia.

Dalkilic, N., \& Kirkbesoglu, E. (2015). The role of financial literacy on the development of insurance awareness. International Journal of Economics and Finance, 7(8), 272-280. https://doi.org/10.5539/ijef.v7n8p272

Dillingh, R., Kooreman, P., \& Potters, J. (2016). Probability Numeracy and Health Insurance Purchase. De Economist, 164, 19-39. https://doi.org/10.1007/s10645-015-9258-8

Driver, T., Brimble, M., Freudenberg, B., \& Hunt, K. H. M. (2018). Insurance literacy in Australia: Not knowing the value of personal insurance. Financial Planning Research Journal, 4(1), 53-75. http://hdl.handle.net/10072/383964

GIZ. (2017). Insurance Literacy Efforts of the German Development Cooperation. In Peterlechner, L. (Ed.), Voices from the field. Bonn and Eschborn, Germany.

Gine, X., Townsend, R., \& Vickery, J. (2008). Patterns of rainfall insurance participation in rural India. The World Bank Economic Review, 22(3), 539-566. https://doi.org/10.1093/wber/lhn015

Hair, J. F. (2011). Multivariate data analysis: An overview. International encyclopedia of statistical science, 904-907. https://doi.org/10.1007/978-3-642-04898-2_395

Hair, J. F., Anderson, R. E., Tatham, R. L., \& Black, W. C. (1995). Multivariate data analysis. New York. NY: Macmillan.

Huston, S. J. (2010). Measuring financial literacy. Journal of Consumer Affairs, 44(2), 296-316. https://doi.org/10.1111/j.1745-6606.2010.01170.x

Kaiser, H. F. (1960). Directional statistical decisions. Psychological Review, 67(3), 160.

Kawinski, M., \& Majewski, P. (2016). Financial Literacy and Insurance Literacy in Poland. Insurance Review, 4, 21-32.

Lin, X., Bruhn, A., \& William, J. (2019). Extending financial literacy to insurance literacy: A survey approach. Accounting \& Finance, 59, 685-713. https://doi.org/10.1111/acfi.12353

Joiner, T. A., Leveson, L., \& Langfield-Smith, K. (2002). Technical language, advice understandability, and perceptions of expertise and trustworthiness: the case of the financial planner. Australian Journal of Management, 27, 25-43. https://doi.org/10.1177/031289620202700102

Mahdzan, N. S., \& Victorian, S. M. P. (2013). The Determinants of Life Insurance Demand: A Focus on Saving Motives and Financial Literacy. Asian Social Science, 9(5). https://doi.org/10.5539/ass.v9n5p274

Mandell, L. (2008). Financial literacy of high school students. In Handbook of consumer finance research (pp. 163-183). Springer: New York, NY. https://doi.org/10.1007/978-0-387-75734-6_10

Marquis S. (1983). Consumer's Knowledge about their Health insurance coverage. Health Care Financing Review, 5(1), 65-80.

McCormack, L., Bann, C., Uhrig, J., Berkman, N., \& Rudd, R. (2009). Health insurance literacy of older adults. Journal of Consumer Affairs, 43(2), 223-248. https://doi.org/10.1111/j.1745-6606.2009.01138.x

McLeod, A., \& Adepoju, O. (2018). Toward a Health Insurance Literacy Model: What Do Young Consumers Know about Insurance? Perspectives in Health Information Management, 1-17.

National Association of Insurance Commissioners. (2010). NAIC holds public hearings on readability standards. [Press Release].

NCAER. (2011). Pre-launch Survey Report of Insurance Awareness Campaign. New Delhi, India: National Council of Applied Economic Research.

Nesleha, J., \& Urbanovsky, K. 2(016). Study of Financial Literacy in the Field of Insurance Products. European Financial System 2016: Proceedings of the 13th International Scientific Conference, 490-495.

OECD. (2008). Improving Financial Education and Awareness on Insurance and Private Pensions. https://doi.org/10.1787/9789264046399-en

OECD. (2014). PISA 2012 Results: Students and Money (Volume VI): Financial Literacy Skills for the 21st 
Century. PISA, OECD Publishing. https://doi.org/10.1787/9789264208094-en

Olapade, M., \& Frolich, M. (2012). The Impact of Insurance Literacy Education on Knowledge, Attitude and Behavior - A Randomized Controlled Trial. Retrieved from https://www.researchgate.net/profile/Markus_Froelich/publication/267773390_The_Impact_of_Insurance Literacy_Education_on_Knowledge_Attitude_and_Behavior_-A_Randomized_Controlled_Trial_Prelimina ry_Version/links/54f5cebd0cf21d8b8a5b81ea.pdf

Pati, S., Kavanagh, J. E., Bhatt, S. K., Wong, A. T., Noonan, K., \& Cnaan, A. (2012). Reading level of Medicaid renewal applications. Academic Pediatrics, 12(4), 297-301. https://doi.org/10.1016/j.acap.2012.04.008

Paez, K. A., Mallery, C. J., Noel, H., Pugliese, C., McSorely, V. E., Lucado, J. L., \& Ganachari, D. (2014). Development of the Health Insurance Literacy Measure (HILM): Conceptualizing and measuring consumer ability to choose and use private health insurance. Journal of Health Communication, 19(2), 225-239. https://doi.org/10.1080/10810730.2014.936568

Politi, M. C., Kaphingst, K. A., Liu, J. E., Perkins, H., Furtado, K., Kreuter, M. W., Shacham, E., \& McBride, T. (2016). A Randomized Trial Examining Three Strategies for Supporting Health Insurance Decisions among the Uninsured. Medical Decision Making, 36(7), 911-922. https://doi.org/10.1177/0272989x15578635

Ramteke, P. (2014). Financial Literacy with Special Reference to Insurance. Research Horizons, 4, 188-194.

Remund, D. L. (2010). Financial Literacy Explicated: The Case for a Clearer Definition in an Increasingly Complex Economy. The Journal of Consumer Affairs, 44(2), 276-295. https://doi.org/10.1111/j.1745-6606.2010.01169.x

Rice, W. (2016). Australia's relentless life underinsurance gap. Retrieved from $\mathrm{http} / /$ ricewarner.com/australias-relentless-underinsurance-gap/

Sanjeewa, W. S., Hongbing, O., Gao, Y., \& Liu, Y. (2019). Decision Making in Personal Insurance: Impact of Insurance Literacy. Sustainability, 11, 1-24. https://doi.org/10.3390/su11236795

Sanjeewa W. S., \& Hongbing, O. (2019). Consumers' insurance literacy: Literature review, conceptual definition, and approach for a measurement instrument. European Journal of Business and Management, 11(26), 49-65. https://doi.org/10.7176/EJBM/11-26-05

Stempel, J. W. (2006). Stempel on insurance contracts (3rd ed.). New York, NY: Aspen Publishers.

Tennyson, S. (2011). Consumers' insurance literacy: Evidence from survey data. Financial Service Review, 20, $165-179$

Tilley, L., Yarger, J., \& Brindis, C. D. (2018). Young Adults Changing Insurance Status: Gaps in Health Insurance Literacy. Journal of Community Health, 43, 680-687. http://doi.org/10.1007/s10900-018-0469-1

Uddin, M. A. (2017). Microinsurance in India: Insurance literacy and demand. Business and Economic Horizons, 13(2), 182-191. http://dx.doi.org/10.15208/beh.2017.14

Urbanovsky, K., \& Nesleha, J. (2017). Financial Literacy Testing in the Area of Insurance Products. In Jana Kotlebová. Proceedings of the 9th International Conference of Currency, Banking and International Finance. Bratislava: Ekonóm, University of Economics in Bratislava (pp. 271-276).

Vardell, E. (2013). Readability levels of health insurance summary of benefits and coverage forms. The Annual Conference of the Medical Library Association, Boston, MA. Retrieved from https://www.ncbi.nlm.nih.gov/pmc/articles/PMC3878945/

Wells, B., Epermanis, K., \& Gibson, J. P. (2015). The Effect of Insurance Education on Consumer Attitudes: A Study of the Property and Casualty Industry. Journal of Financial Education, 41(3), 47-65. https://www.jstor.org/stable/24573699

Zait, A., \& Bertea, P. B. (2014). Financial Literacy - Conceptual Definition and Proposed Approach for a measurement. Journal of Accounting and Management, 4(3), 37-42.

\section{Copyrights}

Copyright for this article is retained by the author(s), with first publication rights granted to the journal.

This is an open-access article distributed under the terms and conditions of the Creative Commons Attribution license (http://creativecommons.org/licenses/by/4.0/). 